\title{
A tentative approach to the molecular structure of humic acids: The spectral evidence for a derivation of humic acids from plant-borne esters. 2. Infrared and chemical analyses
}

\section{G. Minderman}

Research Institute for Nature Management, Arnhem, the Netherlands

Key words: humic acids, spectrophotometry

Received 29 September 1978; accepted 1 June 1979

\section{Summary}

Two questions remain important in the theoretical approach to the problem of the origin of humic acids: what chemical arrangement underlies the molecular structure of the humic acids and from what substances do they originate? The discussion of humic acid formation has frequently been based on the view that all substances in fallen leaves are available to the microbes and that the humic acids originate from the waste products produced during and after this consumption. In the present study, evidence was obtained that the secondary metabolism of the higher plants gives rise to products in the form of monomers which are directly polymerized into humic acids, as suggested, for instance, by Bruckert \& Jacquin (1971). In the secondary metabolism of microbes, there is an analogous formation of these acids via the mineralization of the assimilable substances (carbohydrates, proteins, etc.) in the litter.

On the basis of the study reported here, in combination with Part 1 of this study (Minderman, 1979a), the following hypotheses were formulated:

1) humic acids are polyesters;

2) humic acids originate as monomers in the secondary metabolism of both higher and lower plants;

3) humic acids are formed in an acid environment (including high-moor peat);

4) the formation of humic acids is promoted by desiccation, particularly under alkaline conditions;

5) humic acids show keto-enol tautomerism;

6) humic acids can form semi-quinones and therefore also stable radicals;

7) humic acids derive their colour from these radicals.

\section{Introduction}

The formation of humus, and particularly of humic acids, is still poorly understood. These unsolved problems are not very relevant for agriculture, which is mainly based on local empirism, but for the evaluation of the agricultural potential of soils 
on a world-wide scale a fundamental understanding of the processes involved in humus formation is of great importance. This also holds for nature management, where the planning of a change in regimen requires a knowledge of humus formation under both types of management, because the type of humus present is closely related to the type of vegetation.

What is humus in fact? On the one hand, humus consists of unchanged or only slightly changed parts of plants and their content of such metabolic products as carbohydrates, fats and proteins (Handley, 1954) as well as chlorophyl derivatives and carotenes, and, on the other hand, the highly resistant humic acids or their precursors. These components of humus, together with the mineral soil, form the environment of the roots of plants. When the soil does not have an adequate humus content, plant growth is difficult if not impossible. The higher plant cannot simply create a suitable environment for its roots: the process by which dead material is converted into humus is too complicated, because of the indispensable role played by micro-organisms and lower animals.

In dependence on the nature of the local vegetation, a certain average amount of (easily) assimilable vegetable substance becomes available each year for the vital processes of the micro-organisms and lower animals. This leads to the mineralization of such substances into water and carbon dioxide, except for a few unusable waste products which occur in higher plants as well. ${ }^{14} \mathrm{C}$ dating has shown that the ultimately formed humic acids are highly resistant. A mean persistance of a few centuries is common, and in deeper layers this period varies from one thousand to five thousand years (Scharpenseel et al., 1968; Paul, 1970). Since the amount of carbon in an entire soil profile is rather small (normally $5-15 \mathrm{~kg} / \mathrm{m}^{2}$ ) and the annual supply is estimated at $0.5 \mathrm{~kg} / \mathrm{m}^{2}$, the annual production of highly resistant material must be small and represents only a fraction of the supply (Minderman, 1968). In humus chemistry, these resistant materials are assigned to the humic acids, i.e. that fraction of the organic material in the soil which is soluble in diluted alkali, from which it can be precipitated with acid. This is also the fraction of the organic material which is the most valuable, due to its capacity to adsorb ions and to take up water. The importance of the humic acids is indicated by the fact that they account for more than half of the organic matter in the uppermost soil layers.

The resistance of these humic acids to microbial degradation is very high. There are only a few reports in the literature referring to some degree of breakdown of humic acids by fungi (Latter \& Burges, 1960; Mathur \& Paul, 1967; Mathur, 1970; Paul, 1970), and a bacterial effect is unknown. This resistance must therefore be sought in the molecular structure of these waste products which (almost) all living organisms are unable to use. The competition of all organisms in the soil, both with respect to each other and to the food supply, is such that they can be expected to exploit all the material they can take up to the utmost, because it is their only source of energy. Any organism that manages to obtain a little more energy than the others is better able than they to maintain the species. This also means that no species can permit itself to produce more waste material than is absolutely necessary; in other words, only universally resistant residual 
matter is produced; matter which as microscopial analysis of dead leaves has shown (Handley, 1954), can also be formed in higher plants.

It is clear from the results obtained by many investigators over many decades that it is difficult, if not impossible, to draw final conclusions about the molecular structure and origin of the humic acids from the results obtained with destructive analytic techniques. For the current state of our knowledge, reference is made to various reviews (Kononova, 1958; Anon. 1959; McLaren \& Peterson, 1967; McLaren \& Skujins, 1971; Paul \& McLaren, 1970, 1975; Soil Science 111, 1971; de Borger, 1972; Schnitzer \& Kahn, 1972; Povoledo \& Golterman, 1975). Current views on the origin and formation of these acids are briefly summarized in the following (see also Felbeck, 1965).

1. After the death of higher plants, their lignin reacts with proteins of the soil flora, giving rise to a lignin protein complex considered to be rather resistant and, after Waksman (1936), called humic acid. The resistance of this complex has been questioned, however. For instance, unlike humic acid, the lignin protein complex from oak litter proved to be dissolved by $2 \% \mathrm{HNO}_{3}$ (Minderman \& Bierling, 1968). At this strenght, this acid is an excellent agent for the elimination of lignin (Hisey, 1946). Hurst (1967, p. 29) states, more or less in agreement with Waksman: 'Partially metabolized aromatic residues from the parent vegetation and newly synthesized microbial products undergo free radical polymerization reactions to produce biologically inert high molecular-weight compounds.' According to this hypothesis, relatively many humic acids, i.e. extremely resistant compounds, must originate from fresh plant material, which is not in accordance with the relatively limited accumulation of humic acids in the soil.

2. From remnants of the higher plants the microbes release extracellularly simple phenols and amino acids which combine, via quinones, into polycondensates: the humic acids (Kononova, 1958; Flaig, 1963; Martin \& Haider, 1971; Martin et al., 1975). It may be assumed that if extracellular substances are released in a biologically very active environment, they will be taken up very rapidly by other microbes as part of the normally severe competition for food. In such an environment there will probably not be sufficient time to convert the excreted material non-biotically into resistant compounds.

3. From plant remnants, the microbes are thought to form intracellularly polymerized compounds which become extracellular humic acids after the organisms die (Felbeck, 1965; Hurst, 1967; Martin et al., 1967; Steinbrenner \& Matschke, 1971; Filip et al., 1974). This concept is based mainly on studies done in monocultures of organisms and with simple compounds. The products which polymerize extracellularly at a $\mathrm{pH}$ of 8 and higher, giving darker products, are usually melanins.

4. Whithin a dying plant cell, humification occurs due to reactions of amino acids, phenols, and newly synthesized quinones. During this autolysis, a heterogeneous product arises as the result of the condensation and polymerization of enzymatically formed free radicals from carbohydrates, proteins, and phenols present there. This takes place before any microbial activity occurs (Handley, 1954; Swaby \& Ladd, 1962). 
Remarks. When the compounds giving rise to a polycondensate are very heterogeneous, there is a greater chance of weak bindings which can be broken by the microbes, which in turn means that the synthesis of resistant humic acids does not commence until some of the compounds have been degraded again.

To these four hypotheses I wish to add a fifth.

5. In each active cell in all plants, both phanerogams and fungi, substances are synthesized which as a rule can only be used by the plant to a small extent or not at all. These waste products are called - not entirely correctly - internal excreta or physiological slag of the basal metabolism, but are better termed secondary plant substances (Zenk, 1967). These products of the secondary metabolism are per definition difficult to degrade and must therefore accumulate in the environment. They are not simple compounds, and are produced in small quantities. These conditions are satisfied by a number of reasonably well-known substances, for instance the tannins in a broad sense, including the leucoanthocyanidins. In tannin-rich plants such as the oak, the tannin content accounts for 5 to $10 \%$ of the dry matter of the leaf. Preparations of these tannin compounds can also contain nitrogen in adsorbed proteins, as do the derivatives, i.e. humic acids, but this protein can be removed from both compounds by repeated stripping with acetone or methanol.

\section{Grounds for regarding tannins as basic elements in the formation of humic acids}

The considerations given under point 5 led us to investigate these secondary compounds as the substances from which humic acids might be formed. We found, for instance, that condensed tannins and the phlobaphenes prepared from them (water-insoluble compounds obtained by boiling tannins with dilute acid) are resistant in enrichment cultures of micro-organisms. After a short period of low-level activity, carbon dioxide production ceases. Lewis \& Starkey (1968) found a similar tendency for tannins in soil, whereas Benoit \& Starkey (1968) found that tannins are bound by cellulose and that the product is resistant to degradation.

By using zinc dust fusion and zinc dust distillation, we obtained very similar products from tannins (e.g. catechin) and humic acids. These techniques are thought to liberate the structural elements present in compounds and also in the humic acid molecule (Hansen \& Schnitzer, 1969). Cheshire et al. (1967, 1968), who also used this technique, reported finding artefacts in their experiments. In our studies catechin gave rise to such compounds as perylene and anthracene with structures bearing no resemblance at all to those present in the original substance, showing this technique to be very unreliable.

In addition to Barton \& Gardner (1966) who found that catechin in hemlock wood can give rise to poorly soluble brown polymers, our hypothesis that catechin could be a basic starting point for humic acid formation seemed to be strengthened by the reaction of catechin with calcium acetate, which, as with humic acid, liberated acetic acid. This can only occur because one of the hydroxyl groups of catechin has a strongly acid reaction and behaves as a carboxyl group, which 
throws special light on the indications of the presence of hydroxyl and carboxyl groups obtained with $\mathrm{Ba}(\mathrm{OH})_{2}$ and calcium acetate in structurally unknown compounds, as also described by van Dijk (1965), Meyer (1962) and Stevenson \& Goh (1972). This means that there might be fewer carboxyl groups in the humic acids than is assumed, which is important with respect to the interpretation of the infrared spectra.

The foregoing indicates why the tannins were chosen as model substances and possible basic elements in our investigation of the structure and origin of the humic acids. On this basis we also included such natural products as ellagic acid, gallic acid, and metadigallic acid. The tannin extracted from mimosa, chestnut, and oak bark and the phlobaphenes obtained by boiling the tannins with mineral acid, as well as the esters of hexadiphenic acid with monosaccharides (substances A-H) isolated from oak leaves. Destructive analysis is in my opinion not likely to improve our understanding of these problems, which explains why a nondestructive spectral analysis was chosen for these studies.

\section{Review of the literature on infrared analysis of humic acids}

The literature contains a large number of infrared spectra given by Durie \& Muray (1957), Dubach (1958), Kumada \& Aizawa (1958), Farmer \& Morrison (1960), Kloke (1963), Dormaar (1967), Theng \& Posner (1967), Mathur (1972), Saiz-Jimenez \& Martin Martinez (1972), and Schnitzer \& Kahn (1972), to mention a few. The published spectra show strong agreement, independent of the origin of the humic acids (Fig. 1). In general, it may be said that this humic acid spectrum is determined mainly by the hydroxyl and carbonyl groups present and to a lesser degree by the presence of nitrogen and aromatic nuclei. As structural elements, mention is made of phenols, quinones, ethers, alcohols, and possibly also esters. It does not seem possible, however, to arrive at a generally acceptable view of the structural composition of the humic acids or of the nature of the polymers on the basis of the various absorption bands, and the literature is full of contradictions.

From their extensive investigation of Phragmites plants and the peat developing from them, Farmer \& Morrison (1960) concluded that hydrolization and methylization of humic acid gives mainly aliphatic ester bonds. They also pointed out that on the basis of the reactions and the spectra, only small amounts of quinones, ketones and aldehydes can be present.

Felbeck (1965, p. 33) assumed that the high yield of phenolic material resulting from alkaline hydrolysis as compared with acid hydrolysis must be due to the presence of esters. Alkaline hydrolysis eliminates one of the splitting products, which does not occur under acid conditions, and thus leads to an equilibrium between ester and splitting products.

Theng \& Posner (1967) found an absorption band near $1720 \mathrm{~cm}^{-1}$ in all of their humic acid spectra and interpreted it as carbonyl-carboxyl in an aliphatic environment. They thought that this absorption band appeared in analogy with the autoxidation of catechol, in which carboxyl originates in a side chain due to 
the opening of the aromatic ring. In addition, the optical density of this band is consistent with the amount of titratable carboxyl (the exchange capacity). When the acid is converted at $\mathrm{pH} 7$, in the potassium salt, this band disappears and its place is taken by strong bands near 1610 and $1380 \mathrm{~cm}^{-1}\left(\mathrm{CO}_{3}\right.$ ion absorption). They do mention a band near $1660 \mathrm{~cm}^{-1}$ which, as far as I have been able to determine, is absent or possibly very weak in all other IR spectra in the literature as well as in ours. These authors concluded that humic acids do not have visible quantities of quinones but do have enolic $\beta$-diketonic and $\alpha \beta$-unsaturated hydroxyketones with conjugation and $\mathbf{H}$ bonds between hydroxyl and carboxyl groups.

Mathur (1972), on the contrary, considers that quinones can be conclusively demonstrated in fulvic acids, whereas Schnitzer (1965) had earlier come to the opposite conclusion from results obtained with a different analytic technique. Whatever the case may be, Mathur (1972) later said (p. 615) of his IR spectra: 'The enolization and aromatization could certainly explain the differences in absorption in the 1580 to $1650 \mathrm{~cm}^{-1}$ region of the salts of humic compounds and their reduction products. Therefore neutralization with $\mathrm{NaOH}$ apparently involved more than salt formation with the $-\mathrm{COOH}$ groups.' In the same year Schnitzer \& Riffaldi (1972) concluded that quinones can be demonstrated by amperometric and potentiometric titration, in a way not previously applied. According to them, on this basis, $70 \%$ of the total amount of $\mathrm{C}=\mathrm{O}$ groups in humic acids and $20 \%$ in fulvic acids belong to quinone groups; and no correlation was found between the amounts of quinones and of radicals. Maximov \& Glebko (1974) too state definitely that quinones are present in humic acids, the amount being 1-3 $\mathrm{meq} / \mathrm{g}$. Rashid (1972) gives a corresponding value of $1.8-4.7 \mathrm{meq} / \mathrm{g}$, obtained according to Kukkarenko \& Yekaterinina. The importance assigned to the presence or absence of quinones is explained by the fact that all current theories on the formation of humic and fulvic acids are based not only on the aromatic character but also on the occurrence of hydroxy-quinones. Thus, an extensive conjugated system of quinones is held responsible for the typical dark colour and the fact that humic acids can be reduced to leuco-humic acids with sodium amalgam (Farmer $\&$ Morrison, 1960). In the present state of our knowledge, colour determination by a quinoid system does not seem very likely. The same holds for the view that quinones can be polymerized to humic acids, since the former do not have the conditions for mesomerism (Steinbrenner \& Matschke, 1971, p. 15).

Méndez \& Stevenson (1966) were unable to confirm the results of Burges et al. (1964) by breaking ether bonds via sodium amalgam in an aqueous milieu. According to Vogel (1956) ether bonds cannot be broken in this way, which means that the phenols obtained by Burges and his co-workers must have been differently bound and that ether bonds play little or no role in the structure of humic acids.

Hydrolysis of humic acids gave Riffaldi \& Schnitzer (1972) an enhancement of the absorption bands in the IR spectrum at 1730,1630 , and $1200 \mathrm{~cm}^{-1}$, ascribed respectively to $\mathrm{C}=\mathrm{O}$ or $\mathrm{COOH}$; aromatic $\mathrm{C}=\mathrm{C}, \mathrm{H}=$ bonded $\mathrm{C}=\mathrm{O}$ or carbonyl double-bond conjugated with $\mathrm{C}=\mathrm{O}$ and $\mathrm{C}-\mathrm{O}$ stretch; or $\mathrm{OH}$ deformation in $\mathrm{COOH}$ groups. This picture is in agreement with our humic acids. 
In spectra of acid-boiled humic acid (ABHA) of Podzol B, Rendzina, Antarctic peat, and $\mathrm{H}$ layer from bracken, Burges et al. (1964) found bands at 1630 and $1730 \mathrm{~cm}^{-1}$. Dormaar (1967) published spectra which on the whole are in good agreement with ours. He notes for a number of his spectra: 'Shows complete podzolic character', this conclusion being drawn from the ascending slope, i.e., the decrease in absorption in the spectrum between 2500 and $1800 \mathrm{~cm}^{-1}$, which he thought to be dependent on the molecular weight of the humic acids and the nature of the vegetation. In my spectra, however, the podzols too show 'the chernozem character' of Dormaar (spectrum 17).

\section{Analysis of the infrared (IR) spectra}

In IR spectral studies, the most characteristic bands of the humic acids should be determined first. Unfortunately, few of the spectra in the literature are shown in a form making it possible to read the adsorption bands. This is due to differences in representation, in the instruments used, and the use of the wavelength versus frequency for the abscissa. Transformation of the spectra from wavelength to frequency and vice versa often gives unsatisfactory results.

To indicate the most characteristic bands of the humic acids, I have shown not only all the bands observed but also the number of times they occurred in

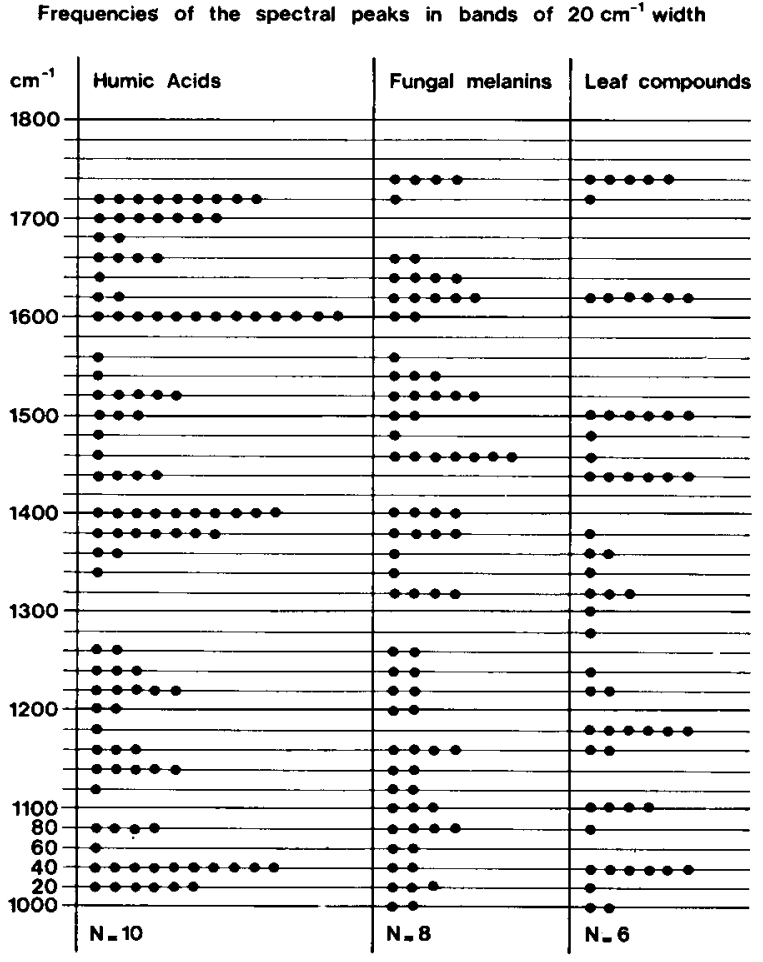

Fig. 1 The spectra originate from many referenced authors for the humic acids, from Haider et al. (1967 \& 1975) and Saiz-Jimenez \& Martin Martinez (1972) for the fungal melanins and from Schmidt et al. (1967), Seikel \& Hillis (1970) and this paper for the leaf compounds. 
the cases I have cited (Fig. 1). Generally speaking, the results show that the humic acids are characterized by the following absorption bands: $3400,3320,3100$ (?), $2930,2860,2500 \mathrm{sh}, 1720,1700,1660,1610-1590,1520,1440,1400,1380$, 1240-1220, $1160-1140,1080$ and 1040-1030. The most frequently occurring bands are in italics and the most prominent in bold type.

Schnitzer \& Khan (1972, p. 72) and Schnitzer (1975) mention as the most important bands those at 3400, 2900, 1725, 1630, 1450,1400, 1200 and 1050 . This series it not entirely in agreement with our findings, which are closer to those of Filip et al. (1974), Saiz-Jimenez \& Martin Martinez (1972) and Bailly (1974). Our data are also not in agreement with those of Stevenson \& Goh (1972), who refer to bands at 1720 and $1600 \mathrm{~cm}^{-1}$.

Dormaar (1967) and Kloke (1963) published a very large number of spectra, but it is extremely difficult to read the frequencies of the absorption bands. Although the data of Schnitzer (1971) and Schnitzer \& Khan (1972, their Figs 4-5 and 4-8) are not identical with ours, photographic conversion to the scale of our spectra showed that their results for humic and especially for the fulvic acids agree closely with, for example, humic acid from calcareous soil of Hackfort I after 6 $N \mathrm{HCl}$ (spectrum 1). This is even more remarkable because this humic acid definitely has none of the characteristics of a fulvic acid. It is striking to note the enhancement of the $1720 \mathrm{~cm}^{-1}$ band in spectrum 1 after boiling with $6 \mathrm{~N}$ $\mathrm{HCl}$ as compared with the original compound in spectrum 2 . This suggests that the carboxyl band of non-ionized acids is enhanced by the presence of a strong mineral acid. On the basis of the spectra obtained, the fulvic acids, have a more strongly acid character than the humic acids due to the domination of the 1720 $\mathrm{cm}^{-1}$ band. However, this phenomenon has also been found in the Black Chernozem humic acids (Dormaar, 1967) in fractions 1-5 from a Sephadex column, although it could hardly be distinguished in the spectrum of the original humic acid. This band was also found in humic acids treated with peracetic acid and $\mathrm{HCl}$ (Meneghel et al. 1972) and also in the ABHA and fulvic acids reduced or not reduced (Mathur, 1972), and in humic acids from redbrown earth (Theng \& Posner, 1967). This band is also very pronounced in ellagic acid (spectrum 3) as an expression of the thrice unsaturated lactone formation.

The other more important bands are the one at $1600\left(1610-1590 \mathrm{~cm}^{-1}\right)$ and the one near $1660 \mathrm{~cm}^{-1}$. Much can be said about the interpretation of these bands. The latter might indicate quinones whose distinct manifestation is observed by overlapping bands (Mathur, 1972). Few spectra show bands in this area (Dormaar et al., 1970). I think it most likely that the ones in this area are to be attributed to intermolecularly bound acids and salts such as are found under chelation of hydroxybenzoylic acid (e.g. sodium salicylate; Avram \& Mateescu, 1972), in which the lactone ring of ellagic acid becomes a hydrogen bond, i.e. a chelate with a band at $1665 \mathrm{~cm}^{-1}$. This must hold for many acids and also for dimer orthohydroxy acids, where the distance between $\mathrm{C}=\mathrm{O}$ and $\mathrm{HOC}$ amounts to about $0.26 \mathrm{~nm}$.

The bands between 1640 and $1620 \mathrm{~cm}^{-1}$ as well as those at 1220 and 1440 $\mathrm{cm}^{-1}$ (phenols), might be ascribed to an aromatic source. It remains possible that 


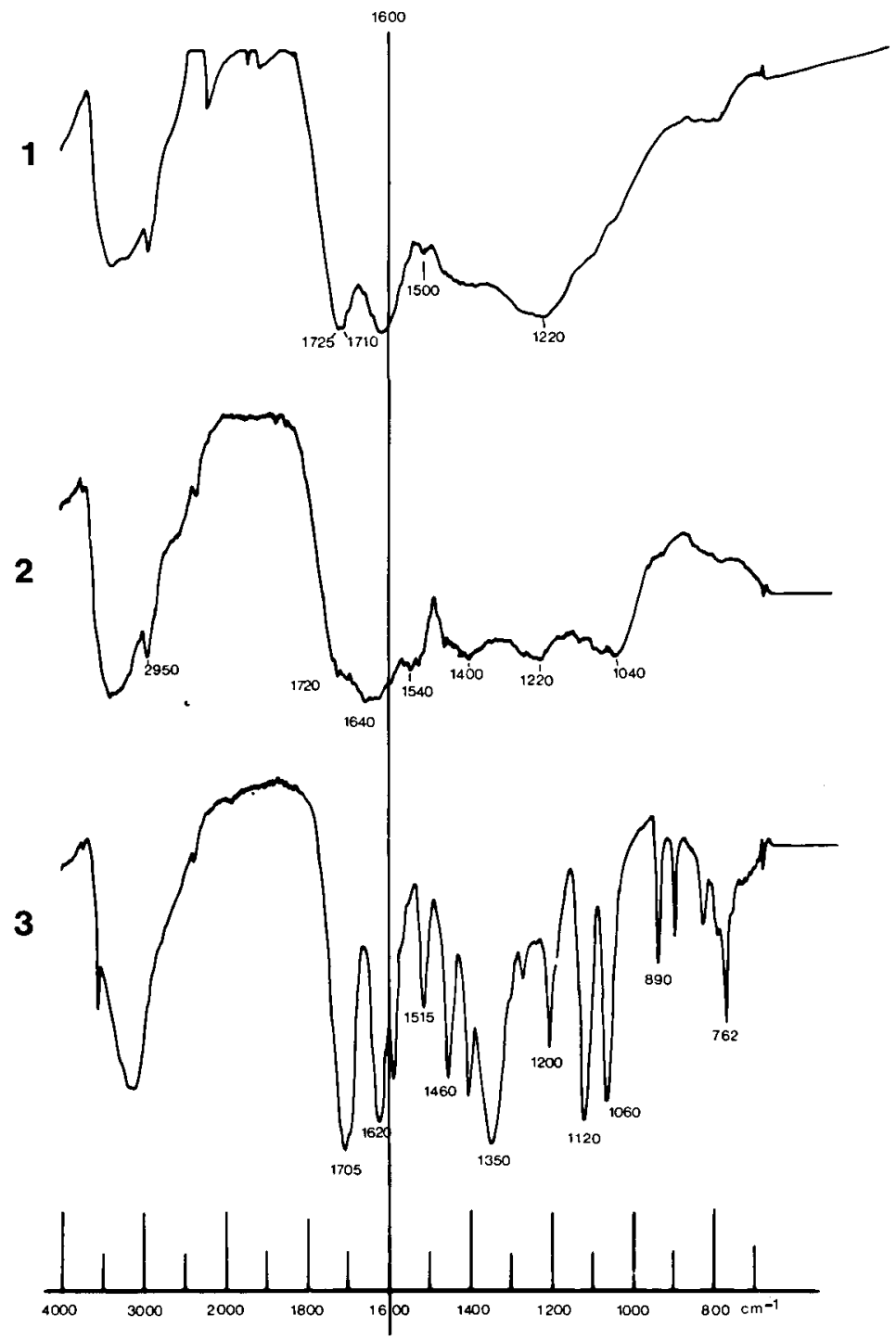

Fig. 2A.

Spectrum 1. Acid-boiled humic acid of a mixed broadleaf forest soil, calcareous sand, Hackfort I, the Netherlands.

Spectrum 2. Humic acid of Hackfort I.

Spectrum 3. Ellagic acid 4, 4', 5, 5', 6, 6'-hexahydroxydiphenic acid, 2, 6, 2', 6'-dilactone. After refluxing with $6 \mathrm{~N} \mathrm{HCl}$, only the bands 1515,1270 and $1200 \mathrm{~cm}^{-1}$ are intensified in absorption. 

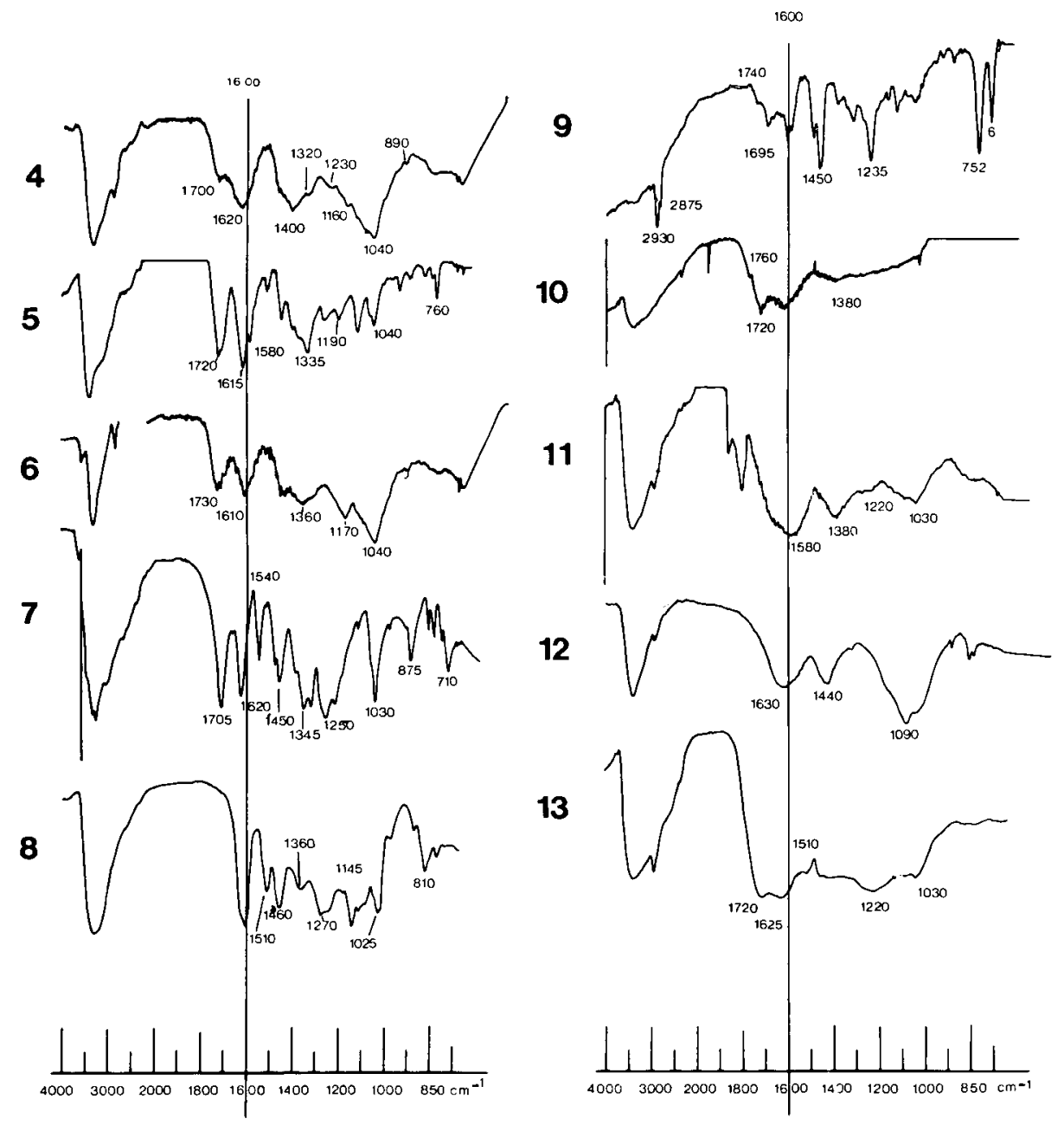

Fig. 2B.

Spectrum 4. Compound $F, 4,4^{\prime}, 5,5^{\prime}, 6,6^{\prime}$-hexahydroxydiphenic acid glucose ester, isolated from green oak leaves after weak hydrolysis.

Spectrum 5. Idem, after $24 \mathrm{~h}$ at $105^{\circ} \mathrm{C}$ in a closed tube with $6 \mathrm{~N} \mathrm{HCl}$.

Spectrum 6. Compound A, a hexahydroxydiphenic acid glucose ester, isolated from green oak leaves.

Spectrum 7. Gallic acid, 2, 4, 5-trihydroxybenzonic acid.

Spectrum 8. Catechin, 3, 3', 4', 5, 7-pentahydroxy flavan.

Spectrum 9. Flavan, derived from catechin by reduction.

Spectrum 10. Humic acid of Hackfort I, dried at $200{ }^{\circ} \mathrm{C}$; cf. spectrum 2.

Spectrum 11. Humic acid of Hackfort I, the potassium 'salt'.

Spectrum 12. Hackfort I, the total organic matter extracted from soil by flotation and sieving. Spectrum 13. Humic acid of Hackfort I after treatment by the mixture of Halse $\left(\mathrm{H}_{2} \mathrm{SO}_{4}-\mathrm{HCl}\right.$ conc). 
MOLECULAR STRUCTURE OF HUMIC ACIDS. 2

Table 1. Humic acid Hackfort $\mathbf{I}$ after various treatments. The absorpion bands $\left(\mathrm{cm}^{-1}\right)$.

\begin{tabular}{|c|c|c|c|c|c|c|c|}
\hline Spectrum No & 12 & 2 & 10 & 1 & 13 & 11 & \\
\hline \multirow[t]{8}{*}{ Substance } & $\begin{array}{l}\text { total } \\
\text { organic } \\
\text { matter }\end{array}$ & $\begin{array}{l}\text { humic } \\
\text { acid }\end{array}$ & $\begin{array}{l}\text { humic } \\
\text { acid } \\
\text { dried } \\
\text { at } 200{ }^{\circ} \mathrm{C}\end{array}$ & ABHA & $\begin{array}{l}\text { humic } \\
\text { acid } \\
\text { after } \\
\text { 'Halse' }\end{array}$ & $\begin{array}{l}\text { humic } \\
\text { acid } \\
\text { 'K salt' }\end{array}$ & \\
\hline & & 1720 & $\begin{array}{l}1760 \text { sh. } \\
1720\end{array}$ & $\begin{array}{l}1740 \mathrm{sh} . \\
1720\end{array}$ & 1720 & & ester \\
\hline & 1640 & 1640 & & & & & \\
\hline & & & 1620 & 1620 & 1625 & 1580 & $\begin{array}{l}\text { inter- } \\
\text { molecular }\end{array}$ \\
\hline & 1540 & & & $\begin{array}{l}1500 \mathrm{sh} . \\
1460 \mathrm{sh} .\end{array}$ & 1510 & & $\begin{array}{l}\text { H-bonded } \\
\text { esters, } \\
\text { enol ions }\end{array}$ \\
\hline & 1400 & & & & 1420 & & \\
\hline & & 1380 & & $1380 \mathrm{sh}$. & & $\begin{array}{l}1380 \\
1270\end{array}$ & phenols \\
\hline & & & & $\begin{array}{l}\text { keto } \\
\text { form }\end{array}$ & & $\begin{array}{l}\text { enol } \\
\text { form }\end{array}$ & \\
\hline
\end{tabular}

The conclusions indicated in the last column are not considered definitive; the argumentation is given in the text.

1620 and $1640 \mathrm{~cm}^{-1}$ are part of the ester pattern; because in esters $\mathrm{A}$ and $\mathrm{F}$, which occur in oak leaves, they are also present under acid conditions; this suggests chelation, albeit at a very low frequency. The band at $1620 \mathrm{~cm}^{-1}$ is also found in gallic acid, ellagic acid and in catechin in all conditions, and the one at $1610 \mathrm{~cm}^{-1}$ in flavones (spectra 4-9).

The main question concerning humic acid is whether it is an ester. Almost all authors mention a band at $1720 \pm 10 \mathrm{~cm}^{-1}$ in the spectra, which is usually considered to represent the absorption of the carboxyl group of an acid (Elofson, 1957). Two authors (Farmer \& Morrison, 1960) refer to a possible ester origin, but this view has received little support. The band has been found in all of our humic acid preparations, sometimes only as a small shoulder but always demonstrable in both the standard preparation and the ABHA obtained with $6 N \mathrm{HCl}$ (Burges et al., 1964). It remains distinct after an acid treatment and disappears with alkali or is sometimes present as a weak shoulder (spectra 1, 2, 14 to 21) a reaction which is entirely consistent for acids and their salts. The presence of aliphatic chains $\left(-\mathrm{CH}_{2}\right.$ absorption near $\left.2900 \mathrm{~cm}^{-1}\right)$ is not pronounced and is unrelated to the acid character of the humic acids. Thus on the basis of the demonstrated carboxyl groups, no long chain fatty acid would be present. On the other hand, insoluble fatty acids are not expected under limited chain indications, and would in any case absorb far below 1720 due to dimerization or extensive $\mathbf{H}$ binding. The latter consideration also holds strongly for arylic acids.

The conversion of humic acid by alkali into the 'salt' causes little change in the rest of the spectrum, even in the area of $\mathrm{OH}$ absorption, which does not 

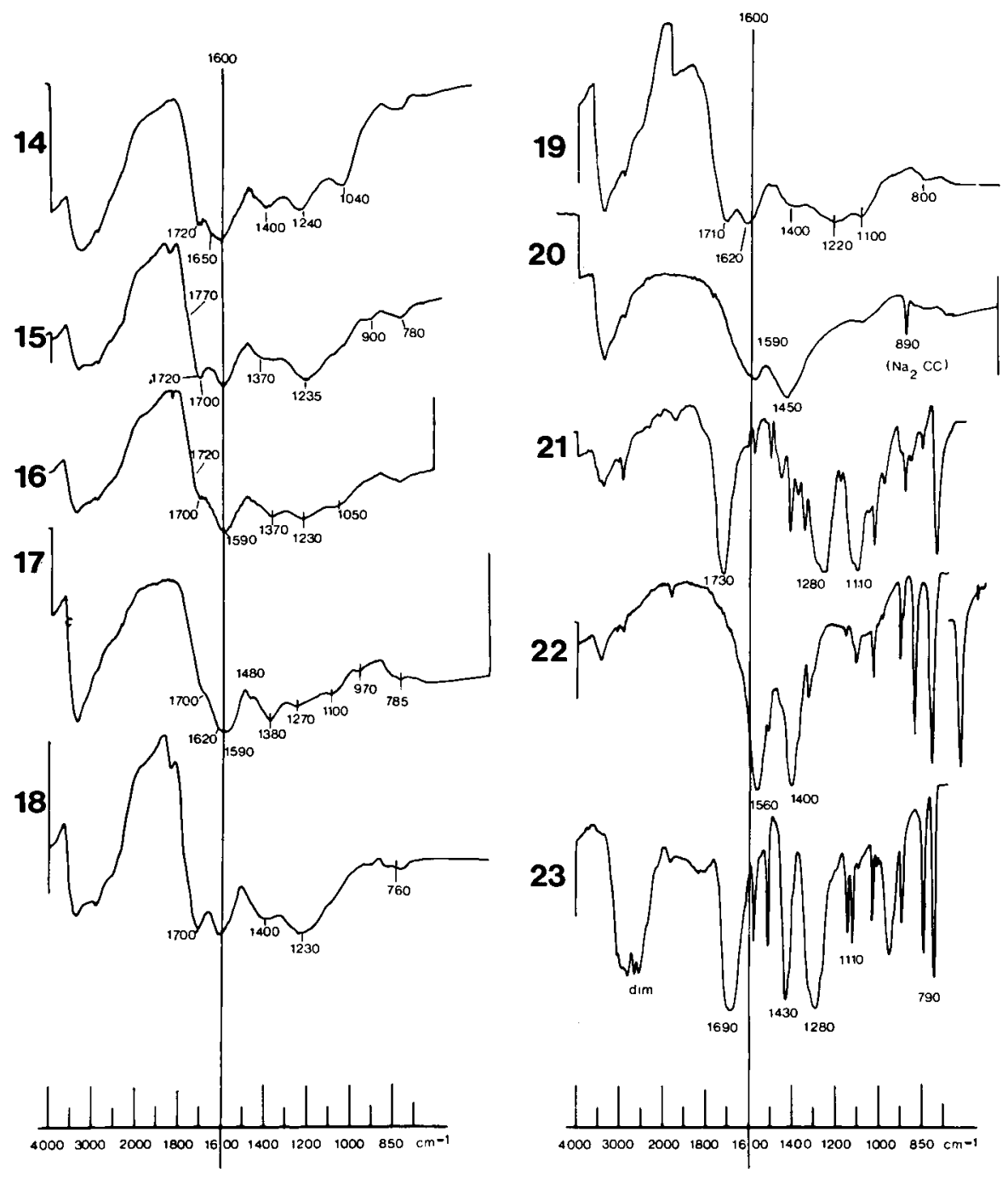

Fig. 2C.

Spectrum 14. Humic acid of Melfort soil Canada, chernozem.

Spectrum 15. Acid-boiled humic acid (ABHA) of Melfort soil after acid treatment.

Spectrum 16. Humic acid of Melfort soil, the sodium 'salt'.

Spectrum 17. Humic acid of Podsol $B_{h}$, Deelen, the Netherlands.

Spectrum 18. ABHA of Podsol $B_{h}$, Deelen.

Spectrum 19. ABHA of Hackfort I acidified to $\mathrm{pH} 5.5$ after treatment with conc. alkali.

Spectrum 20. ABHA of Hackfort $I$ the sodium salt, with some $\mathrm{Na}_{2} \mathrm{CO}_{3}$, visible in the spectrum.

Spectrum 21. Terlenka, polyterephthalic acid glyptal.

Spectrum 22. Idem, dried at $\mathbf{p H} 10$, the salt form.

Spectrum 23. Idem, dried at $\mathrm{pH} 5$, acidified after dissolving in strong alkali. 
favour the presence of acids. This is strongly supported by the fact that the 1615$1590 \mathrm{~cm}^{-1}$ band of the carboxylate ion shows little or no increased absorption due to the action of the alkali. In this connection the polyester Terlenka (terephthalic acid glyptal) spectra 21-23 may be mentioned as a comparable case. After solution in strong alkali followed by acidification to $\mathrm{pH} 5$ the carbonyl bands at 1720-1730-1745 give rise to a main absorption band near $1690 \mathrm{~cm}^{-1}$, which was originally absent but is also present in the spectrum of the standard preparation of humic acids. For Terlenka this band indicates the liberation of an arylic acid, other changes also occur in the spectrum, particularly around 1300 and $1110 \mathrm{~cm}^{-1}$. Adjustment to $\mathrm{pH} 10$ causes the 1690 band to disappear, being replaced by one at 1560 belonging to the carboxylate ion. This is a very striking change, which also occurs near $1400 \mathrm{~cm}^{-1}$ with the disappearance of the 1240 $\mathrm{cm}^{-1}$ band (ester of arylic acid) and the appearance of strong bands between 3000 and $2500 \mathrm{~cm}^{-1}$.

Support for the ester concept derives mainly from the isolation of a small number of esters from oak leaf by Bierling (unpublished), the best known being substance $F$, a hexahydroxydiphenic acid glucose ester, spectrum 24 . This compound has, in common with a number of others isolated from oak leaves, characteristics which in many respects agree with those of humic acids. In the first place it has a distinct electron paramagnetic resonance (EPR) signal, partially attributable to structural resonance and partially to a semi-quinone resonance, also occurring in several humic acids. In the second place, the structure is known from the work done by Schmidt et al. (1967), and Seikel \& Hillis (1970) mention the IR absorption bands in addition to the chromatographic data. It is an ester with six active hydroxyl groups on the aryl rings and many possibilities for intraand intermolecular formation of hydrogen bonds. The model ester has the characteristic that alkalinity gives rise to a structure whose spectrum shows considerable resemblance to the salt of a carboxylic acid, spectra 25, 26, 27 . After acidification the spectrum returns to its original form. This means that under the given conditions hydrolytic disassociation of the ester does not occur and that the change in the spectrum must be due to keto-enol tautomerism. Hydrolysis occurs under more severe conditions, as also for the polyester Terlenka in about $50 \% \mathrm{NaOH}$. Acidification of this solution does not restore the original spectrum; on the contrary, that of terephthalic acid appears. Terlenka is difficult or impossible to dissolve with strong mineral acids, and under certain conditions $6 \mathrm{~N} \mathrm{HCl}$ has little or no influence on the spectrum of substance $\mathrm{F}$. The levelling seen in the finger-print region points more to polymer formation, such as a polydepside, seen in the formation of compound G, spectra 28,29, 30 .

The interpretation of the $1740-1700 \mathrm{~cm}^{-1}$ band is simple in our material, because the structure is known. For an ester this band lies very low and for an aromatic acid very high. For diphenic acid spectrum 31 , there can be no doubt about the acid group, for meta-digallic acid, spectrum 32 , the acid band is raised by about $10 \mathrm{~cm}^{-1}$ due to the presence of the ester bond.

In spectrum 33, this depside shows strong correspondence with substance $F$ and is also further esterized by boiling with $6 \mathrm{~N} \mathrm{HCl}$, probably to possibly chain-type 


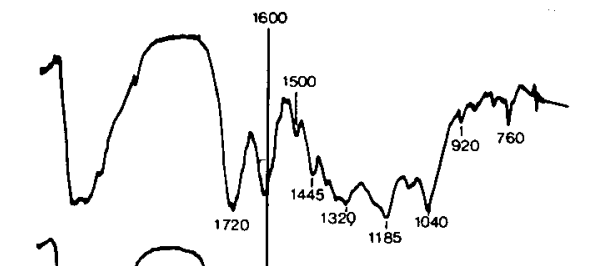

25

26 25

27

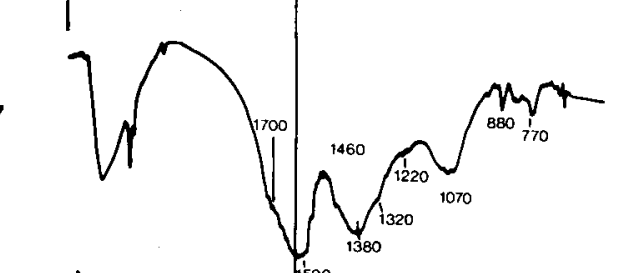

28

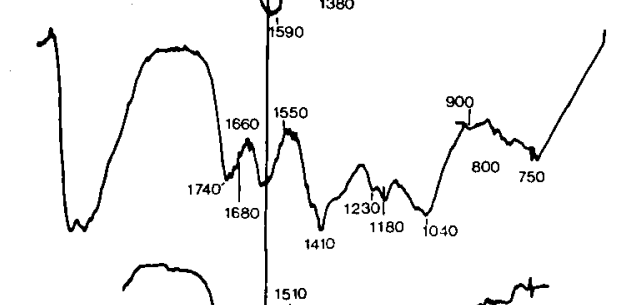

29

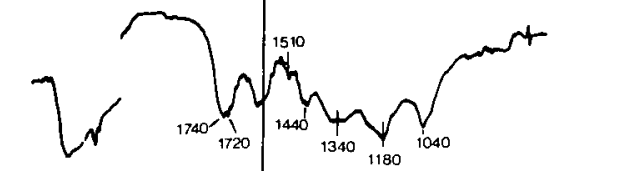

Fig. 2D.

Spectrum 24. Compound F, pure, acidified

Spectrum 25. Idem, after strong alkali treatment, acidified to $\mathrm{pH} \mathrm{5}$, and dried. Spectrum 26. Idem, pure, neutral. Spectrum 27. Idem, the 'sodium salt'. Spectrum 28. Compound G, pure, neutral.

Spectrum 29. Compound F neutral, solid form, some months after isolation from the leaf extract.

Spectrum 30. Compound A, $24 \mathrm{~h}$ at $105{ }^{\circ} \mathrm{C}$ in a closed tube with $6 \mathrm{~N} \mathrm{HCl}$. 


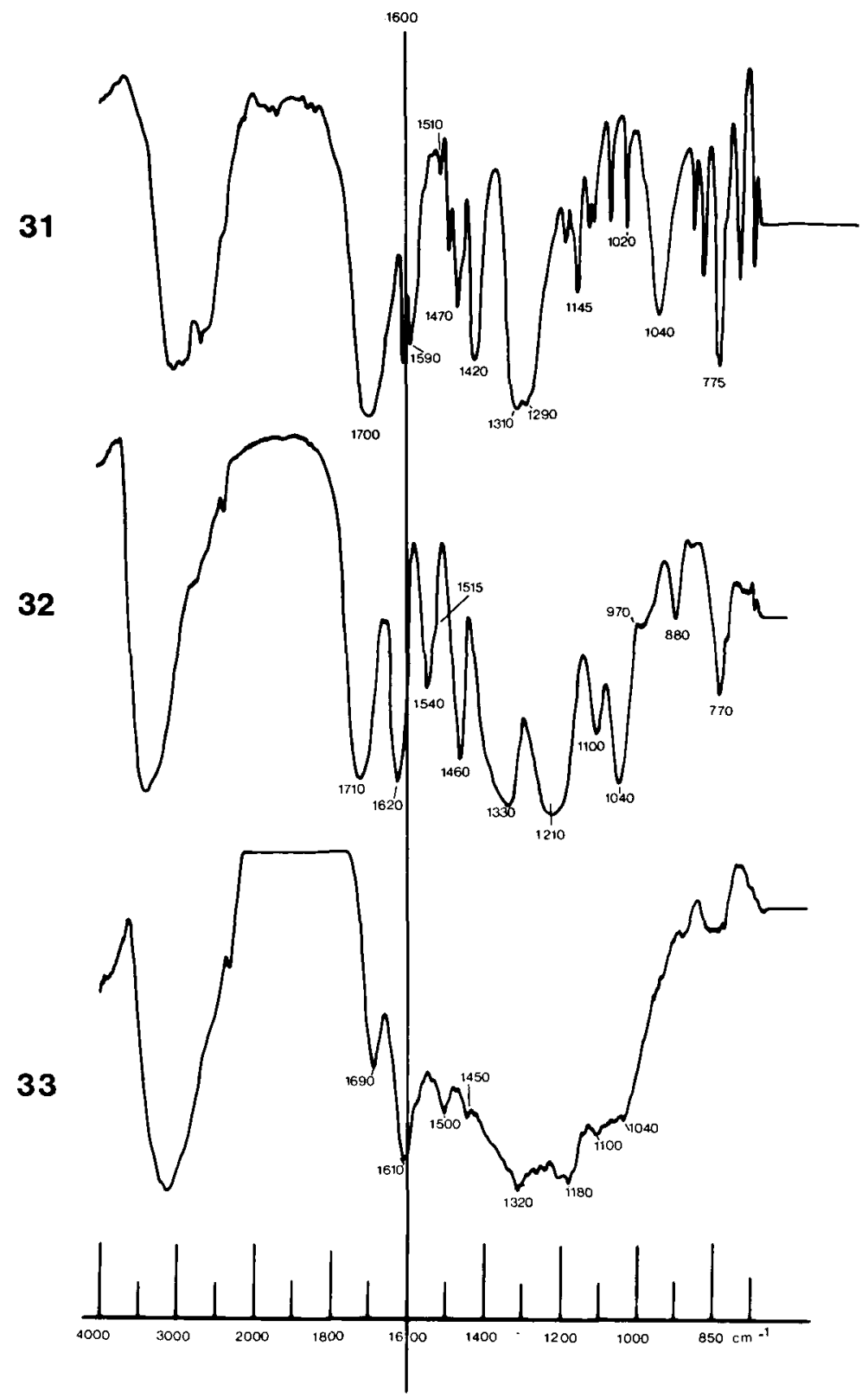

Fig. 2E.

Spectrum 31. Diphenic acid, 2, 2'-biphenyldicarboxylic acid.

Spectrum 32. Meta-di-gallic acid, 5,6-dihydroxy-3-carboxy-phenyl ester of gallic acid. Spectrum 33. Meta-di-gallic acid after $24 \mathrm{~h}$ at $105^{\circ} \mathrm{C}$ in a closed tube with $6 \mathrm{~N} \mathrm{HCl}$. 
polydepsides, as may be concluded from the leveling in the region below 1500 $\mathrm{cm}^{-1}$. It is known that aryl sugar esters can easily be polymerized (Haworth et al., 1946) and there are also indications that humic acids have an aromatic component bound to an aliphatic component (Clark \& Tan, 1969; Tan \& McCreery, 1970; Cameron et al., 1972; H'in \& Orlov, 1973; Ogner, 1973). There is a marked resemblance between the HA spectrum and that of $F$ after boiling with $6 \mathrm{~N} \mathrm{HCl}$ (at $105^{\circ} \mathrm{C}$ ). Hydrolysis of $\mathrm{F}$ makes it possible to isolate ellagic acid deriving from diphenic acid and which may be considered the diphenic dilactone. This substance occurs in many dicotyledonous plants where, in combination with sugars and possibly gallic acid, it makes strong tanning compounds, such as the hydrolysable tannins. Unlike metadigallic acid, after long boiling in with $6 \mathrm{~N} \mathrm{HCl}$ ellagic acid does not show any change or levelling of the spectrum, i.e. under acid conditions there is no polymerization due to the presence of the lactone structure.

Tannins, as their practical use indicates, prevent the decay of labile proteins and are themselves highly resistant to the action of microbes. This is evident even for simple esters of gallic acid. In pharmacology, for instance, these compounds are used to control oxidation and deterioration (Sabalitschka, 1953; Forgo, 1969).

In addition to these hydrolysable tannins, condensed tannins play an at least equally important role in nature. The condensation products, called phlobaphenes, are not soluble in water or organic solvents, or acids, but are dissolved by alkali and, to the best of our knowledge, are unaffected by microbial action. Their spectra and products also agree strongly with those of the humic acids, to which, in our opinion, they belong. As model substance for humic acids, we wish to discuss first of all the hydrolysable tannins, with occasional reference to phlobaphene spectra; these phlobaphenes have been mentioned mainly in connection with the EPR approach to the structure of humus. The hydrolysable tannins, all of which have ellagic acid or gallic acid or both, do not occur naturally in gymnosperms, pteridophytes, or monocotyledons (Bate-Smith, 1962).

The absorption bands (Fig. 1) indicate that in the infrared region the humic acids form a rather homogeneous group. This also holds for the melanins of fungi and also for the group of model substances, the esters of hydroxydiphenic acid.

A high degree of correspondence can be distinguished between the patterns of the various groups. All of them show spectra which are in good agreement or are virtually identical with one belonging to another group. At the very least there seems to be a tendency for the basic structure of the groups to be similar, which might suggest a time-dependent stronger polymerization in the direction of the humic acids. This holds for the highly purified preparations in a neutral or acid state. After solution in alkali or conversion into an alkaline salt, the spectral picture is drastically changed, leaving only a few pronounced absorption bands, as was the case for the above-mentioned esters. Although reference is made repeatedly in the literature to the salts of humic acids, it is preferable, in analogy with the esters, to speak here of keto-enol tautomerism. The relationship is 


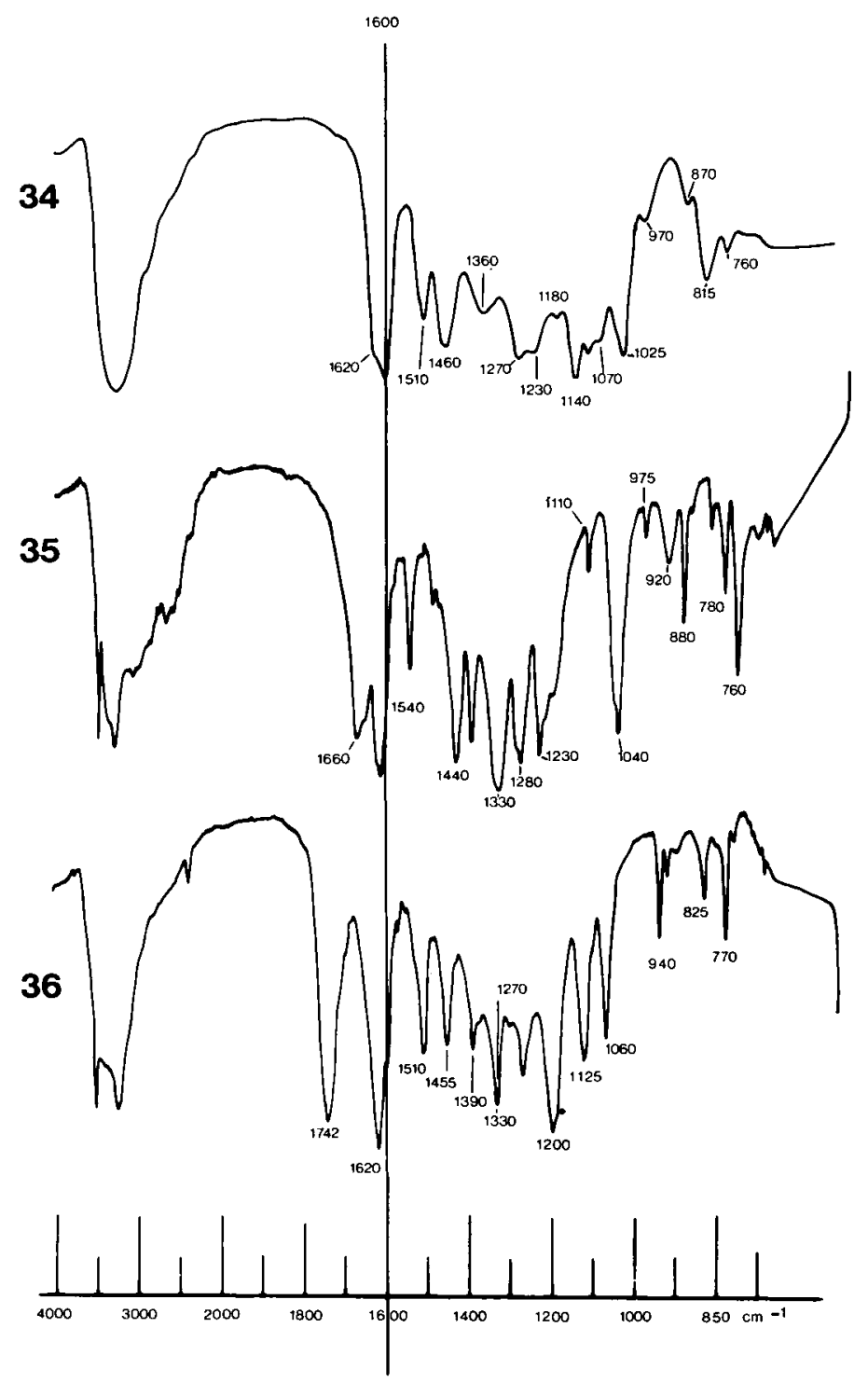

Fig. 2F.

Spectrum 34. Catechin.

Spectrum 35. Gallic acid.

Spectrum 36. Catechin + gallic acid boiled in $12 \% \mathrm{HCl}$, the ester. 
indicated by the preceding spectra; in the EPR spectra the characteristic signal of substance $F$ can be followed via extracts of leaves and litter to its persistence in the humic acids. This is also the case for the keto-enol tautomerism in the IR spectra, which means that the characteristics of known esters can be followed as far as their presence in the very old humic acids.

In addition, the characteristic ability of the esters to polymerize in an acid environment (e.g. meta-digallic acid) into even more resistant compounds and the frequent occurrence of these esters and depsides in nature, also makes this idea promising as a starting point for humus chemistry. No matter how complex or confused the final polymolecules may be, if agreement can be reached on the primary formative principle, i.e. esterification or depsidation, two approaches will be available for the solution of the problem of the humic acids. In the first place there is the synthetic approach via natural plant substances, and in the second place the destructive analytic approach based on the breakdown of esters in combination with non-destructive spectral analysis. As already mentioned, not only hydrolysable but also condensed tannins unquestionably play a role in humic acid formation. These tannins are strongly correlated with the presence of leucocyanidins and are thus also present in the gymnosperms, ferns, woody dicotyledons, and in some monocotyledons (Bate-Smith, 1962). These compounds too are easily polymerized under acid conditions (Evelyn et al., 1960, p. 46), which makes them highly resistant. In monomer form they occur naturally rather frequently as anthocyanidins and catechin derivatives The catechins have one very strong acid-reactive hydroxyl group, as can be inferred from their reaction to calcium acetate, in which acetic acid is liberated, and, like substance $F$, can form enol, quinone, semi-quinone, and radicals. Under mineral acid conditions catechin, spectrum 34, combines with gallic acid, spectrum 35 , to form esters, spectrum 36 , giving rise to a strong $1742 \mathrm{~cm}^{-1}$ band. Keto-enol conversion can be induced and after the reaction catechin and gallic acid cannot be demonstrated separately.

Catechin also has the characteristic of undergoing condensation to homopolymers in an acid environment (Byung-Zun Ahn \& Gstirner, 1970). This is expressed in our spectra in a levelling of the spectrum (37 and 38), which then closely resembles that of a humic acid after boiling with $6 \mathrm{~N} \mathrm{HCl}$, spectrum 39 . The occurrence of trimers with a possibly spiral structure has been demonstrated in plants by Byung-Zun Ahn (1974a, b). Cameron et al. (1972) also mention the possibility of a spiral structure for their humic acids.

In my opinion, two basic components, i.e. glucose esters of trihydroxybenzoic acid and flavone derivates, form fundamental components in the material from which humic acids arise. These compounds do not occur in all plants. They are absent in the more 'modern' group of dicotyledons and in the monocotyledons, although the precursors are present in both. In the formation of humic acids from this material, the mediation of microbes is probably indispensable. These secondary organisms can synthesize, from many simple substances, products with a strong resemblance to humic acids (Filip et al., 1974) and with many points of agreement with substance $F$. The degree of condensation is probably not sufficient for true humic acids. These microbial products are formed under favourable conditions by 


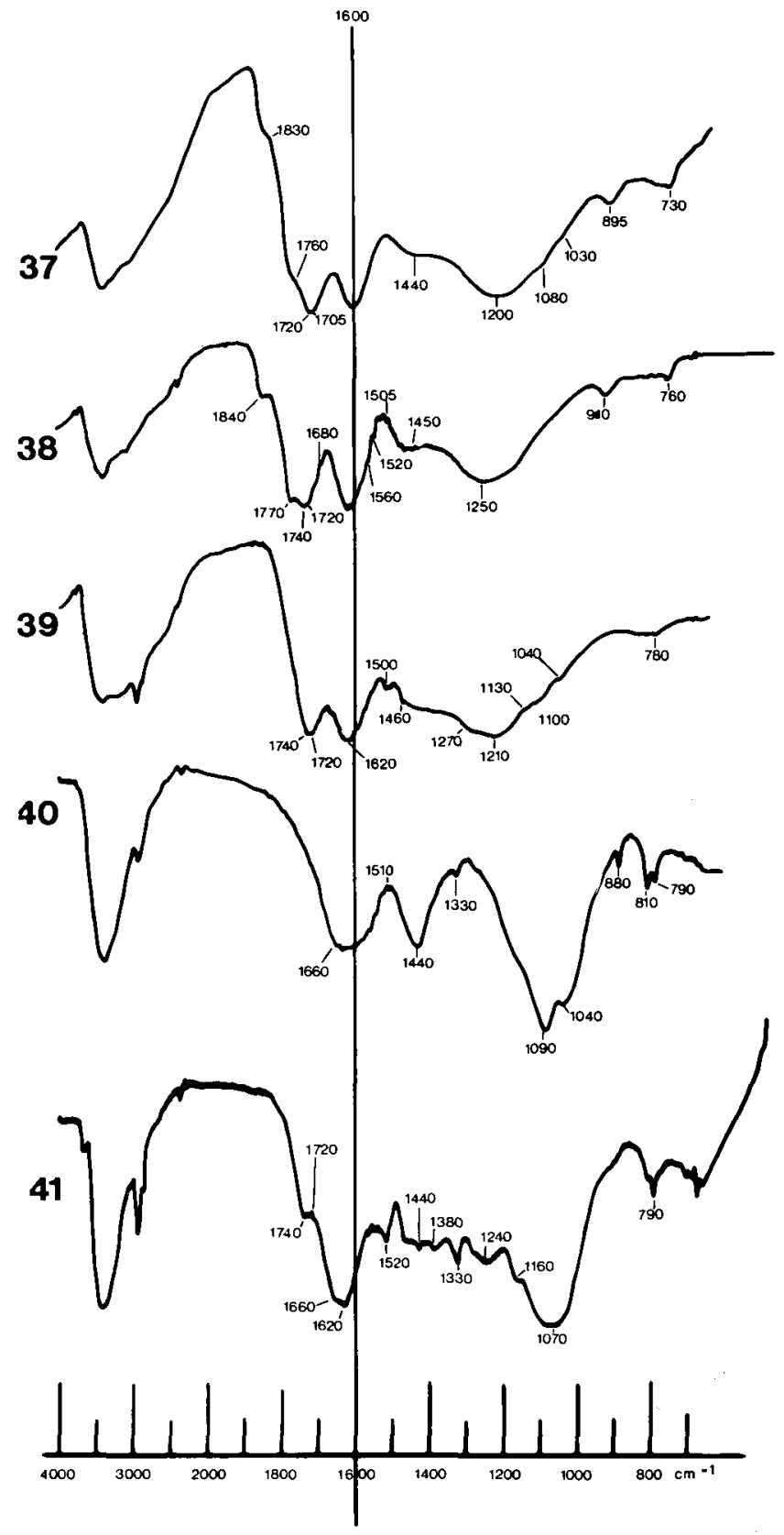

Fig. 2G.

Spectrum 37. Catechin, after $24 \mathrm{~h}$ at $105{ }^{\circ} \mathrm{C}$ in closed tube with $6 \mathrm{~N} \mathrm{HCl}$.

Spectrum 38. Catechin, after $1 \mathrm{~h}$ refluxing $2 \% \mathrm{HNO}_{3}$.

Spectrum 39. ABHA Hackfort I.

Spectrum 40. Total organic matter isolated from Hackfort I soil by flotation and sieving. Spectrum 41. F-layer, oak forest, mortype, Hackfort I, dried and milled. 
monocultures in culture media but in rather small amounts $(\ll 10 \%$ according to Steinbrenner \& Matschke, 1971, and $>10 \%$ according to Haider \& Martin, 1967) comparable to the level of production of other secondary metabolic products in the higher plants (e.g. tannin).

Besides microbes and acid conditions, another condensating agent is severe desiccation of the material produced, leading to irreversible substances (as in black peat), probably due to the transformation of hydrogen bonds into simple covalent bonds when the atoms come into very close proximity. In soils with a high $\mathrm{pH}$ value, i.e. under alkaline conditions, which do not promote condensation, desiccation of the precursors of humic acid promotes the formation of true humic acids, because the ultimate products under both acid and alkaline conditions and also the precursors are identical. The fact remains that the humic acids in both kinds of soil are indistinguishable, whereas the organic matter in one shows an enol character and that in the other a keto character (spectra: 40, 41, organic matter Hackfort I and F layer Hackfort III), depending on the $\mathrm{pH}$.

\section{References}

Anon., 1959. Symposium on humic acid. Sci. Proc. Roy. Dublin Soc., Ser. A (4) 1960. 195 pp. Avram, M. \& Gh. Mateescu, 1972. Infrared spectroscopy. Wiley Interscience, New York.

Bailly, J. R., 1974. Spectroscopie infra-rouge de quelques acides humiques. Pl. Soil 40: 285-302.

Barton, G. M. \& J. A. F. Gardner, 1966. Brown stain formation and the phenolic extractives of Western Hemlock (Tsuga heterophylla (Raf.) Sarg.). Department of Forestry, Canada, Publication No 1147.

Bate-Smith, E. C., 1962. The simple polyphenolic constituents of plants. In: W. E. Hillis (Ed.), Wood extractives and their significance to the pulp and paper industries: 133-158. Academic Press, New York.

Benoit, R. E. \& L. Starkey, 1968. Inhibition of decomposition of cellulose and some other carbohydrates by tannin. Soil Sci. 105: 291-296.

Borger, R. de, 1972. Huidige kennis omtrent de bouw der humusstoffen. Landbouwtijdschrift 25 (1): $37-50$.

Bruckert, S. \& F. Jacquin, 1971. Contribution à l'étude de la condensation des composés organiques aux cours de l'humification en milieu podzolique. Bull. Ec. Nat. Super. Agron. Nancy 13 (1/2): 28-35.

Burges, N. A., H. M. Hurst \& B. Walkden, 1964. The phenolic constituents of humic acid and their relations to the lignin of the plant cover. Geochim. cosmochim. Acta 28: 15471554.

Byung-Zun Ahn, 1974a. Ein Catechintrimer aus der Eichenrinde. Arch. Pharmaz. 307: 186-197.

Byung-Zun Ahn, 1974b. Catechingerbstoffe aus der Tormentilla-Wurzel. Arch. Pharmaz. 307: 241-250.

Byung-Zun Ahn \& F. Gstirner, 1970. Gewinnung von Catechin-Dimeren durch Säurekondensation. Arch. Pharmaz. 303: 720-724.

Cameron, R. S., B. K. Thomson, R. S. Swift \& A. M. Posner, 1972. Molecular weight and shape of humic acid from sedimentation and diffusion measurements on fractionated extracts. J. Soil Sci. 23: 394-408.

Cheshire, M. V., P. A. Cranwell, C. P. Falshaw, A. J. Floyd \& R. D. Haworth, 1967. Humic acid. II. Structure of humic acids. Tetrahedron 23: 1669-1682.

Cheshire, M. V., P. A. Cranwell \& R. D. Haworth, 1968. Humic acid. III. Tetrahedron 24: 5155-5167.

Clark, F. E. \& K. H. Tan, 1969. Identification of a polysaccharide ester linkage in humic 
acid. Soil Biol. Biochem. 1: 75-82.

Dijk, H. van, 1965. Zuurgroepenanalyse en kationenbinding bij huminezuren. Thesis, University of Groningen, $175 \mathrm{pp}$.

Dormaar, J. F., 1967. Infrared spectra of humic acids from soils formed under grass or trees. Geoderma 1: 37-46.

Dormaar, J. F., M. Metche \& F. Jacquin, 1970. Extraction and purification of humic acids from a Rendzina $A_{h}$ and a Podzol $B_{h}$ Horizon. Soil Biol. Biochem. 2: 285-293.

Dubach, P., 1958. Uber die Dekarboxylierung der organischen Substanz des Bodens. Promotionsarbeit, ETH-Zürich, No 2731.

Durie, R. A. \& A. Murray, 1957. A study of the infra-red absorption spectra of soils. Aust. J. appl. Sci. 8: 335-338.

Elofson, R. M., 1957. The infra-red spectra of humic acids and related materials. Can. J. Chem. 35: 926-931.

Evelyn, S. R., E. A. Maihs \& D. G. Roux, 1960. Condensed tannins. 5. The oxidative condensation of $(+)$-catechin. Biochem. J. 76: 23-27.

Farmer, V. C. \& R. S. Morrison, 1960. Chemical and infra-red studies on phragmites peat and its humic acid. Sci. Proc. Roy. Dublin Soc., Ser. A, I: 85-104.

Felbeck jr., G. T., 1965. Structural chemistry of soil humic substances. Adv. Agron. 17: 327-368.

Filip, Z., K. Haider, H. Beutelspacher \& J. P. Martin, 1974. Comparisons of I.R.-spectra from melanins of microscopic soil fungi, humic acids and model phenol polymers. Geoderma 11: 37-52.

Flaig, W., 1963. The chemistry of humic substances. Report FAO-IAEA Technical Meeting: 103-127. Pergamon Press.

Flaig, W., 1967. Chemical composition and physical properties of humic substances. Studies about humus. Humus Planta 4: 81-112.

Flaig, W., 1975. An introductory review on humic substances. Proc. int. Meet. humic Subst. (Nieuwersluis, 1972): 19-42. Pudoc, Wageningen.

Forgo, I., 1969. Physikalisch-chemische Eigenschaften und Antioxydans-Wirkung einiger neuer Gallussäure-Ester-Derivate. Thesis, ETH-Zürich, No 4410. $101 \mathrm{pp}$.

Haider, K. \& J. P. Martin, 1967. Synthesis and Transformation of Phenolic Components by Epicoccum nigrum in relation to Humic acid formation. Proc. Soil Sci. Soc. Am. 31: 766-772.

Haider, K., J. P. Martin, Z. Filip \& E. Fustec-Mathon, 1975. Contribution of soil microbes to the formation of humic components. Proc. int. Meet. humic Subst. (Nieuwersluis, 1972): 71-85. Pudoc, Wageningen.

Handley, W. R. C., 1954. Mull and Mor formation in relation to forest soils. For. Comm. Bull., London No 23. $116 \mathrm{pp}$.

Hansen, E. H. \& M. Schnitzer, 1969. Zn-dust distillation and fusion of a soil humic and fulvic acid. Proc. Soil Sci. Soc. Am. 33: 29-36.

Haworth, W. N., H. Gregory \& L. F. Wiggins, 1946. Some derivatives of simple carbohydrates containing unsaturated substituents J. chem. Soc.: 488-491.

H'in, N. P. \& D. S. Orlov, 1973. Photochemical destructions of humic acids (in Russ.) Pochvovedenie 1: 73-79.

Hisey, W. O., 1946. Delignification of wood. In: L. E. Wise (Ed.), Wood chemistry. Reinhold, New York. 900 pp.

Hurst, H. M., 1967. Processes occurring during the formation of humic substances. Studies about humus. Humus Planta 4: 28-38.

Kang, K. S. \& G. T. Felbeck, Jr., 1965. A comparison of the alkaline extract of tissues of Aspergillus niger with humic acids from three soils. Soil Sci. 99: 175-181.

Kloke, A., 1963. Die Humusstoffe des Bodens als Wachtstumfactoren. Paul Parey, Berlin \& Hamburg. 96 pp.

Kononova, M. M., 1958. Die Humusstoffe des Bodens, VEB-Deutscher Verlag der Wissenschaften, Berlin, xi +342 pp. 
Kumada, K. \& K. Aizawa, 1958. The infra-red spectra of humic acids. Soil Pl. Food 3: 152-159.

Latter, P. \& A. Burges, 1960. Experimental decomposition of humic acid by fungi. Trans. 7th Int. Congr. Soil Sci. (Madison, Wisc.) Vol 2: 643-647.

Lewis, J. A. \& R. L. Starkey, 1968. Vegetable tannins, their decomposition and effects on decompositon of some organic compounds. Soil Sci. 106 (4): 241-247.

Martin, J. P. \& K. Haider, 1971. Microbial activity in relation to soil humus formation. Soil Sci. 111 (1): 54-63.

Martin, J. P., K. Haider \& E. Bondietti, 1975. Properties of model humic acids synthesized by phenoloxidase and autoxidation of phenols and other compounds formed by soil fungi. Proc. int. Meet. humic Subst. (Nieuwersluis, 1972): 171-186. Pudoc, Wageningen.

Martin, J. P., S. J. Richards \& K. Haider, 1967. Properties and decomposition and binding action in soil of 'humic acid' synthesized by Epicoccum nigrum. Proc. Soil Sci. Am. 31 (5): 657-662.

Mathur, S. P., 1970. Degradation of soil humus by the fairy ring mushroom. Pl. Soil 33: 717-720.

Mathur, S. P., 1972a. Infra-red evidence of quinones in soil humus. Soil Sci. 113 (2): 136-139.

Mathur, S. P., 1972b. An infra-red and chemical investigation of the acid tinchloride method of determining quinones in humus. Proc. Soil Sci. Soc. Am. 36: 611-616.

Mathur, S. P. \& E. Paul, 1967. Microbial utilization of soil humic acid. Can. J. Microbiol. 13: 573 .

Maximov, O. B. \& L. I. Glebko, 1974. Quinoid groups in humic acids. Geoderma 11: 17-28.

McLaren, A. D. \& G. H. Peterson (Ed.), 1967. Soil biochemistry, Vol. 1. Marcel Dekker, New York, 509 pp.

McLaren, A. D. \& J. Skujins (Ed.), 1971. Soil biochemistry, Vol. 2. Marcel Dekker, New York. $527 \mathrm{pp}$.

Méndez, J. \& F. J. Stevenson, 1966. Reductive cleavage of humic acids with sodium amalgam. Soil Sci. 102: 85-93.

Meneghel, R., Chr. Petit-Sarlotte \& J. M. Bloch, 1972. Sur la caractérisation et l'isolement des produits de dégradation d'un acide humique après oxydation peracétique. Bull. Soc. chim. Fr. 7: 2997-3001.

Meyer, W., 1962. Die Bestimmung funktioneller Gruppen an Huminsubstanzen aus Böden. Thesis, ETH Zürich, No 3225.81 pp.

Minderman, G., 1968. Additon, decomposition and accumulation of organic matter in forests. J. Ecol. 56: 355-362.

Minderman, G. \& J. Bierling, 1968. The determination of cellulose and sugars in forest litter. Pedobiologia 8: 536-542.

Minderman, G., 1979a. A tentative approach to the molecular structure of humic acids: The spectral evidence for a derivation of humic acids from plant-borne esters. 1. Electron paramagnetic resonance (EPR) spectra. Neth. J. agric. Sci. 27 :79-91.

Minderman, G., 1979b. A tentative approach to the molecular structure of humic acids: The spectral evidence for a derivation of humic acids from plant-borne esters. 3. Pyrolysismass spectrometry. Neth. J. agric. Sci. 27 (in press).

Ogner, G., 1973. Oxidation of non-hydrolyzable humic residue and its relation to lignin. Soil Sci. 116: 93-99.

Paul, E. A., 1970. Plant components and soil organic matter. In: C. Steelink \& V. C. Runeckles (Ed.), Recent advances in phytochemistry, Vol. 3: 59-104. Meredith Corporation, New York.

Paul, E. A. \& A. D. McLaren (Ed.), 1970. Soil biochemistry, Vol. 3. Marcel Dekker, New York, $334 \mathrm{pp}$.

Paul, E. A. \& A. D. McLaren (Ed.), 1975. Soil biochemistry, Vol. 4. Marcel Dekker, New York. $277 \mathrm{pp}$.

Povoledo, D. \& H. L. Golterman (Ed.), 1975. Humic substances: their structure and function in the biosphere. Proc. int. Meet. humic Subst. (Nieuwersluis, 1972). Pudoc, Wageningen. $368 \mathrm{pp}$. 


\section{MOLECULAR STRUCTURE OF HUMIC ACIDS. 2}

Rashid, M. A., 1972. Quinone content of humic components isolated from the marine environment. Soil Sci. 113 (5): 181-188.

Riffaldi, R. \& M. Schnitzer, 1972. Effects of diverse experimental conditions on ESR spectra of humic substances. Geoderma 8: 1-10.

Sabalitschka, Th., 1953. Zur Auffindung des Antibiotikums Methylgallat und der antimikroben Wirkung der Gallate. Chem. Ztg 77 (4): 108.

Saiz-Jimenez, C. \& F. Martin Martinez, 1972. Acidos humicos de origen fungico. I. Espectros infrarrojos. Ann. Edafol. Agrobiol. 31 (12): 133-140.

Scharpenseel, H. W., M. A. Tamers \& G. Pietig, 1968. Alterbestimmung von Böden durch die Radiokohlenstoffdatierungsmethode. II. Eigene Datierungen. Z. PflErnähr. Bodenk. 119: 44-52.

Schmidt, O. Th., J. Schulz \& H. Fiesser, 1967. Die Gerbstoffe der Myrobalanen. Liebigs Ann. Chem. 706: 187-197.

Schnitzer, M., 1965. The application of infrared spectroscopy to investigations on soil humic compounds. Can. Spectroscopy 10: 121-127.

Schnitzer, M., 1971. Characterization of humic constituents by spectroscopy. In: A. D. McLaren \& J. Skujins (Ed.), Soil biochemistry, Vol. 2. Marcel Dekker, New York. 527 pp.

Schnitzer, M., 1975. Chemical, spectroscopic and thermal methods for the classification and characterization of humic substances. Proc. int. Meet. humic Subst. (Nieuwersluis, 1972): 293-310. Pudoc, Wageningen.

Schnitzer, M. \& S. A. Kahn, 1972. Humic substances in the environment. Marcel Dekker, New York. 327 pp.

Schnitzer, M. \& R. Riffaldi, 1972. The determination of quinone groups in humic substances. Proc. Soil Sci. Soc. Am. 36: 722-777.

Seikel, M. K. \& W. E. Hillis, 1970. Hydrolysable tannins of Eucalyptus delegatensis wood. Phytochemistry 9: 1115-1128.

Steinbrenner, K. \& J. Matschke, 1971. Synthesis of humic substances by soil fungi. Studies about humus. I. Transactions of an international symposium (Prague, 13-17 Sept.). Humus Planta 5: 111-120.

Stevenson, J. \& K. M. Goh, 1972. Infra-red spectra of humic acids and related substances. Geochim. cosmochin. Acta 35: 471-483.

Swaby, R. J. \& J. N. Ladd, 1962. Chemical nature, microbial resistance and origin of soil humus. International Soil Conference, New Zealand. Trans. Int. Soc. Soil Sci., Comm. $I V$ and $V$.

Tan, K. H. \& R. A. McCreery, 1970. The infrared identification of a humopolysaccharide ester in soil humic acid. Commun. Soil Sci. Pl. Anal. 1: 75-84.

Theng, B. K. G. \& A. M. Posner, 1967. Nature of the carbonyl groups in soil humic acid. Soil Sci. 104: 191-201.

Vogel, A. J., 1956. Textbook of practical organic chemistry, 3rd ed. Longmans Green, London. $671 \mathrm{pp}$.

Waksman, S. A., 1936. Humus. Origin, chemical composition and importance in nature. Williams \& Wilkins, Baltimore. 494 pp.

Zenk, M. M., 1967. Biochemie und Physiologie sekundärer Pflanzenstoffe. Ber. Dt. bot. Ges. 80 (9): 573-591. 